\title{
Ontoloji-Epistemoloji İlişkisinde Uzlaştırmac1 Bir Kavram Önerisi: Şemseddin es-Semerkandî'de İtibârî Vücûdî Mâhiyet
}

The Suggestion of a Reconciliatory Concept in The Relation of OntologyEpistemology: The Hypothetical Existential Essence in Shams al-dīn alSamarqandī

\section{Tark TANRIBİLİR}

Dr. Öğr. Gör., Osmaniye Korkut Ata Üniversitesi, İlahiyat Fakültesi, Osmaniye/Türkiye Lecturer Dr., Osmaniye Korkut Ata University, Faculty of Theology, Osmaniye/Türkiye tariktanribilir@osmaniye.edu.tr | orcid.org/0000-0002-4276-9972 | ror.org/03h8sa373

\author{
Makale Bilgisi Article Information \\ Makale Türü Article Type \\ Araştırma Makalesi Research Article \\ Geliş Tarihi Date Recieved \\ 31 Ağustos 202131 August 2021 \\ Kabul Tarihi Date Accepted \\ 30 Kasım 202130 November 2021 \\ Yayın Tarihi Date Published \\ 31 Aralı 202131 December 2021 \\ Intihal Plagiarism
}

Bu makale, iTenticate yazılımı ile taranmıştır. İntihal This article has been scanned with iTenticate tespit edilmemiştir. software. No plagiarism detected.

Etik Beyan Ethical Statement

Bu çalışmanın hazırlanma sürecinde bilimsel ve etik It is declared that scientific and ethical principles ilkelere uyulduğu ve yararlanılan tüm çalışmaların have been followed while carrying out and writing kaynakçada belirtildiği beyan olunur (Tarık this study and that all the sources used have been Tanrıbilir). properly cited (Tarık Tanribilir).

CC BY-NC-ND 4.0 lisansı ile lisanslanmıştır. Licensed under CC BY-NC-ND 4.0 license.

Atif | Cite As

Tanrıbilir, Tarık. "Ontoloji-Epistemoloji İlişkisinde Uzlaștırmacı Bir

(6 Kavram Önerisi: Şemseddin es-Semerkandî'de İtibârî Vücûdî Mâhiyet”.
Kader
$19 / 2$
(Aralik
2021),
583-599.

https://doi.org/10.18317/kaderdergi.989110 


\section{Öz}

Hanefî-Mâtürîdî kelâm geleneğinde felsefî kelâm yöntemini benimseyen ilk âlim olan Şemseddin es-Semerkandî, kelâm, mantık, matematik, astronomi, tefsir, âdâb ve münâzara gibi çeşitli alanlarda eserler vererek kendisini aklî ve naklî ilimlerde kanıtlamış önemli bir Türk-İslâm düşünürüdür. Sisteminin merkezine mantık ilmini yerleștiren Semerkandî, ileri sürülen her görüş ve delili mantıksal analiz etmiş ve hakikate ulaşmayı amaçlamıştır. Onun kesin ve gerçek bilgiye ulaşmayı amaçladığı konuların başında ilahîsıfatlar, evrenin zamansallığı ve Tanrı-evren ilişkisi gelmektedir. Bu meyanda Semerkandî, ilahî ve evrensel sıfatların ontolojik karakterini analiz etmiştir. İşe mâhiyet çeşitlerini analiz etmekle başlayan yazar için itibârî vücûdî mâhiyet kavramı kilit rol oynamaktadır. Vücûdî kavramını, "öz anlamında ve hakikatinde herhangi bir olumsuzluk bulunmayan" şeklinde tanımlayarak vücûdî olmak için bir blok olarak var olmayı ve varlığında hiçbir olumsuzluk bulunmamayı şart koşan Semerkandî, bu kavrama özgün bir açılım getirmektedir.

Taayyünü, "mevcûdu zihnî ve haricî varlıkların tamamından ayrıştıran bir sıfat" olarak tanımlayan Semerkandî, bu kavramın vücûdî bir mâhiyete sahip olduğunu iddia etmektedir. Vâcip varlık hakkındaki kaygıları neticesinde vâcip varlık ile taayyünü özdeş kabul eden İslâm filozoflarını yadsımayan Semerkandî, taayyünü "vücûdî" olarak değerlendirmesi durumunda Tanrı hakkında ortaya çıkabilecek çokluk ve nedenlilik şaibelerini de "itibârı̂” kavramıyla aşmaktadır. Nitekim Semerkandî, varlığı hakikî ve itibarî olmak üzere iki kısma ayırıp hakikî varlığı, "gerçek anlamda mevcûd olup hiçbir aklî varsayıma dayanmayan"; itibarî varlığı ise "aklî varsayıma dayanan" şeklinde tanımlamaktadır. Bu durumda ise gerçek bir çokluk ya da nedenlilikten söz etmek mümkün değildir.

Semerkandî, vücûb kavramının itibarî vücûdî mâhiyet kapsamına girdiğini iddia etmektedir. Zira vücûb, "zâtın zorunlu olarak varlı̆ı gerektirmesi” anlamına gelmektedir. Varlığı gerektiren bir şeyin varlığın hükmünü alması gerektiğinden dolayı vücûbun da vücûdî olması gerektiği çıkarılmaktadır. O, vücûb kavramını nesnel varlıktan bağışık, bilişsel bir oluşum anlamında itibarî mâhiyet ile nitelendirerek Tanrı hakkında ortaya çıkabilecek bir çokluk şaibesinin de önüne geçmektedir.

İmkânın vücûdî bir mâhiyet olarak değerlendirilmesinin Tanrı'nın mûcib bizzât, evrenin ise kadîm olmasını gerektirebileceği endişesiyle kelâmcılar, imkânı ademî bir mâhiyet olarak kabul etmişlerdir. Semerkandî, imkânın hakikî ademî ya da itibarî vücûdî mâhiyet kapsamında kabul edilebileceğini ifade etmektedir. Nitekim imkânın bu minvalde değerlendirilmesi Tanrı'ıı mûcib bizzât, evrenin ise kadîm olması ihtimallerini de ortadan kaldırmaktadır.

Tanrı'ya isnat edilip de O'nun zâtında çokluk oluşturabilecek ya da evrene isnat edilip de evrenin kadîm olmasına neden olabilecek sıfatlar, itibarî vücûdî mâhiyet kapsamında değerlendirilerek Tanrı'nın birliği ve O'nun yegâne kadîm varlık olduğu fikri temellendirilmiştir.

Anahtar Kelimeler: Kelâm, Mantık, Ontoloji, Epistemoloji, Tanrı, Evren, Şemseddin es-Semerkandî.

\section{Abstract}

The Shams al-dinn al-Samarqandī who is the first scholar to adopt the method of the philosophical theology in the HanafiMāturīdī tradition, is an important Turkish-Islamic thinker who has proven himself in rational and transmitted sciences by giving works in various fields such as theology, logic, mathematics, astronomy, tafsir, ādāb al-bahth wa al-munāzara. Placing the science of logic at the center of his system, al-Samarqandi analyzed every opinion and evidence put forward logically and aimed to reach the truth. Divine attributes, the temporality of the universe, and the God-universe relationship are at the forefront of the subjects that he aims to reach certain and real knowledge. In this respect, alSamarqandī analyzed the ontological character of divine and universal attributes. The concept of the hypothetical existential essence plays a key role for the author, who begins by analyzing the types of quiddity. defining the concept of existential as As "that which is without any negativity in its essence and truth", al-Samarqandī, who stipulates to exist as a block and not to have any negativity in its existence, brings a unique expansion to this concept.

al-Samarqandī, who defines determination as "an adjective that distinguishes the existent from all mental and external beings", claims that this concept has an existential essence. As a result of his concerns about necesarry existence, Samarqandi, who does not deny the philosophers who accept the necessary existence and determination as identical, also overcomes the problems of multiplicity and causality that may arise about God, with the concept of "hypothetical", if he considers determination as "existential". As a matter of fact, al-Samarqandi divides existence into two parts as real and hypothetical, and defines the real existence as "existing in the real sense and not based on any rational assumption"; 
defines hypothetical existence as "based on rational assumption". In this case, it is not possible to talk about a real multiplicity or causality.

al-Samarqandi claims that the concept of necessity falls within the scope of the hypothetical existential essence. Because wujûb means "the essence necessarily necessitates existence". It is deduced that wujûb must also be existential, since something necessitating existence must take the judgment of existence. By characterizing the concept of wujûb with hypothetical essence, in the sense of a mental formation that is immune to objective existence, he also avoids the doubt of plurality.

Concerned that the regard of possibility as an existential essence may require God to be necessary per se and the universe to be eternal, theologians accepted possibility as an absent essence. al-Samarqandī states that possibility can be accepted within the scope of true non-existent or hypothetical existential essence. As a matter of fact, evaluating the possibility in this way also eliminates the possibility that God is necessary and the universe is ancient.

Attributes that can be attributed to God and can create a multiplicity in His essence or that can be attributed to the universe and cause the universe to be eternal are evaluated within the scope of the concept of the hypothetical existential essence, and, the idea that God is unique and that he is the only eternal entity is based on this concept.

Keywords: Theology, Logic, Ontology, Epistemology, God, Universe, Shams al-dīn al-Samarqandī.

\section{Giriş*}

İslâm filozofları ve kelâmcılar, Tanrı'nın zâtı bakımından birliğini ve ilahî sıfatların yetkinliğini düşünce sistemlerinin merkezine yerleştirmiş ve bu eksende fikir üretmişlerdir. Tanrı'yı tenzih etme ve O'nu en yetkin manada nitelendirme ortak paydasında buluşan İslâm filozofları ile kelâmcılar, yöntemsel açıdan ayrılmışlardır. Tanrı'nın varlığını temellendirme, O'nu nitelendirme ve Tanrı-evren ilişkisini tasvir etme hususlarında İslâm filozofları ile kelâmcılar, kendi disiplinel anlayışları ve metodolojilerine bağ lı kalarak farklı yaklaşım tarzlarını benimsemişlerdir. Probleme daha ziyade ontolojik perspektifle yaklaşan kelâmcılar, Tanrı'nın zâtında çokluk meydana getirebileceğini düşündükleri ilahî sıfatlar ile evrenin kıdemine yol açabileceğini düşündükleri evrensel sıfatları ademî mâhiyette tasavvur ederek Tanrı-evren ilişkisinde keskin bir ayrım yapmışlardır. Bu sayede kelâmcılar, Tanrı'yı birlemeyi ve ulûhiyet ile özdeşleştirdikleri kıdem sıfatını evrenden bağışlayarak Tanrı'ya tahsis etmeyi amaçlamışlardır. Probleme daha ziyade epistemolojik perspektifle yaklaşan İslâm filozofları ise Tanrı ve evrene ait sıfatların bilişsel ve kavramsal boyutlarını ön plana çıkararak epistemolojik değere sahip olan sıfatları zât hakkında ispat etmiş ve bunları vücûdî mâhiyet kategorisinde değerlendirmişlerdir. İslâm filozofları ile kelâmcılar arasında eklektik bir yaklaşımı benimseyen muhakkik düşünür Şemseddin esSemerkandî, ilahî ve evrensel sıfatları itibarî vücûdî mâhiyet kapsamında değerlendirmektedir. Bu sayede söz konusu sıfatlar, itibârî kabul edilerek onto-teolojik risk iptal edildiği gibi vücûdî kabul edilerek de bunların epistemolojik değerleri kabul edilmiştir.

Kelamcıların ontolojik, filozofların ise epistemolojik yöntemi temel almaları, çeşitli kavramların varoluşsal boyutlarına ilişkin ihtilafa neden olmuştur. Bu ihtilafın gün yüzüne çıtığı kavramlar; taayyün, vücûb li-zâtihî ve imkân olarak belirginleşmektedir. Epistemolojik yaklaşımı merkeze alan filozoflar tarafından vücûdî olarak nitelendirilen söz konusu kavramlar, ontolojik yaklaşımı temele yerleştiren kelamcılar tarafından ise ademî olarak değerlendirilmiştir. Varlık ve bilgi boyutlarını kuşatıcı, küllî bir perspektif ortaya koyan Şemseddin es-Semerkandî de bu kavramları

* $\quad$ Bu makale, aynı yazara ait olan “Şemsüddin Semerkandî̀de Ontoloji ve Epistemoloji Bağlamında Kelam-Felsefe Etkileşimi” adlı doktora tezinden yararlanarak hazırlanmıştır. 
itibârî vücûdî mâhiyet kapsamında değerlendirerek bunların hem varlık hem de bilgi değerlerini aynı anda teslim etmiştir.

\section{1. Şemseddin es-Semerkandî’nin Hayatı ve İlmî Kişiliği}

Müellifimizin tam adı, el-Mevlâ es-Seyyid Şemseddin Muhammed b. Eşref el-Hüseynî/el-Hasenî es-Semerkandî olarak kaydedilmektedir. Asıl adı Muhammed olan yazarımız, daha çok Şemsüddîn Semerkandî ismiyle bilinmektedir. "Semerkandî" ifadesinden onun Semerkant şehrine mensup olduğu anlaşılmaktadır. Semerkandî’nin doğum tarihiyle ilgili kaynaklarda bilgi bulunmamaktadır. İsminin sonuna eklenen "el-Hüseynî” veya "el-Hasenî" künyeleri ile isminin başında bulunan "es-Seyyid" lakabı, onun nesebinin Hz. Peygamber'e ulaştığını göstermektedir. "el-Mevlâ" ve "el-Fâdıl" gibi lakapları, Semerkandî’nin tasavvufî ve derûnî kişiliğine atıf yapmaktadır. Ayrıca çeşitli tabakāt kitaplarında isminin sonuna eklenen "el-hakîm", "elmuhakkik" ve "el-mühendis" gibi unvanlar da onun aklî ilimlerdeki engin bilgisine ve vukûfiyetine işaret etmektedir. ${ }^{2}$

Süleymaniye Kütüphanesi, Laleli Koleksiyonu, 2432 demirbaş numarasiyla kayıtlı evrakta Şemseddin es-Semerkandî̀ye ait es-Sahâifü'l-ilâhiyye, el-Mu'tekadât, İlmü'l-âfâk ve'l-enfüs ve el-Meârif fì şerhi's-Sahâif isimli eserlerin istinsah, tamamlanma ve tashih tarihine ilişkin çeşitli bilgilere ulaşmaktayız. es-Sahâif in sonunda bu nüshanın Seyfü's-Semerkandî lakaplı Muhammed b. Mahmûd b. Ömer el-Gâzî tarafından 706'da Hucend beldesinde tamamlandığı ve 711'de de baştan sona müellife kıraat (قرأ على المصنف) ve mukabele yöntemiyle arz ve tashih edildiği kaydedilmektedir. el-Mu'tekadât adlı eserinin sonunda da bu nüshanın aynı şahıs tarafından yine Hucend beldesinde 709'da tamamlandığ ve Hucend beldesi Necmeddin es-Sağarcî Medresesinde 711'de baştan sona müellif nüshasıyla karşılaştırıldığı kaydedilmektedir. İlmü'l-âfâk ve'l-enfüs 56b numaralı varakta ise bu eserin de diğer iki eser gibi müellifin yanında kıraat (قرأ عنده) ve mukabele yöntemiyle arz ve tashih edildiği kaydedilmektedir. el-Meârif'in sonunda ise bu nüshanın ilk kez 712'de müellife kıraat ve mukabele yöntemiyle tashih edildiği, müellifin vefatından sonra da ikinci kez 702'de tashih edildiği kaydedilmektedir. Ayrıca müellifin Şevval ayının 22. günü 702'de vefat ettiği belirtilmektedir. Bu kitabın telif tarihinin 705 olması da verilen bilgiler arasındadır. $\mathrm{Bu}$ nüshanın, müellifin vefatından sonra ikinci kez mukabele edildiği kaydı, 712'deki ilk mukabelenin müellifin hal-i hayatında gerçekleştiğini göstermektedir. Gerek ikinci mukabele gerekse de müellifin vefatıyla ilgili verilen bilgilerin çeliştiği açıktır. Zira ikinci mukabelenin birinci mukabeleden önce yapılması, müellifin kitabını vefat ettikten sonra yazması ya da bu nüshayı vefatından sonra tashih etmesi mümkün değildir. "Ve işrîn" (20) rakamını ifade eden bu nüshadaki bir tashih kaydı, hem müellifin 722'de vefat ettiğine hem de ikinci mukabelenin aynı yılda gerçekleştiğine $1 s ̧ 1 k$ tutarak söz konusu çelişkileri düzeltmektedir. ${ }^{3}$ Semerkandînnin vefat tarihiyle ilgili bilgi veren bütün tabakāt kitapları 711-712 yıllarından daha erken bir tarihe işaret etmektedir. Dolayısıyla Semerkandî’nin 711-712 yıllarında hayatta olduğunu açıkça ortaya koyan

Kâdîzâde Rûmî, Şerhu Eşkâli't-te’sîs (İstanbul: Süleymaniye Kütüphanesi, Ayasofya, 2712), 13a.

Kâtip Çelebî, Süllemü'l-vusûl ilâ tabakāti'l-fuhûl, haz. Selahaddin Uygur (İstanbul: Merkezü'l-Ebhâs li't-Târîh ve'lFünûn ve's-Sekāfe el-i̇slâmiyye, 2010), 3/108.

Şemseddîn es-Semerkandî, Kelâm mecmuası (İstanbul: Süleymaniye Kütüphanesi, Laleli Koleksiyonu, 2432), 34a, 52b, 56b, 136b, 153b, 169a. 
bu kayıtlar, Semerkandînnin vefat tarihi hakkında tabakāt kitaplarında zikredilen bilgilerin tamamını çürütmektedir. Semerkandînnin vefat tarihiyle ilgili 711-712 yıllarından geç olarak 722'den başka bir vefat tarihi kaydı bulunmadığına göre onun vefat tarihinin 22 Şevval 722 (3 Kasım 1322) olarak tespit edilmesi daha doğru gözükmektedir. Şemseddin es-Semerkandînnin kelâm, mantık, matematik, astronomi, tefsir, âdâb ve münâzara gibi alanlarda birçok eseri bulunmaktadır.

\section{Mâhiyet Taksimi}

Varlık, bütün benliğimizi kuşatan apriori bir kavramdır. Nesnelerin fiilî durumları onların vücûdlarıdır. Öte yandan şeyler, varlıktan da ibaret değildir. Nitekim onların varlıklarına ek olarak insan, at, taş, masa ve dağ gibi özel yönleri de bulunmaktadır. Varlıkta ortak olan nesnelerin birbirinden ayrıldığı bu özel yöne mâhiyet adı verilmektedir. Böylece nesnelerde vücûd ve mâhiyetten oluşan bir ontolojik terkip meydana gelmektedir. Varlıkları teşkil eden vücûd elementi, tüm varlıkların ortak yönünü; mâhiyet elementi ise varlık türlerini birbirinden ayıran özel yönlerini ifade etmektedir. ${ }^{4}$ Mâhiyetler, mevcûdâtın bir bileşenini oluşturan ontolojik bir hüviyete sahip olmasının yanı sıra varlıkların kimliğini temsil eden, insan bilgisini ya da küllî ilim yapmayı olanaklı hale getiren epistemolojik bir karakteri de yansıtmaktadır.

Semerkandî, mâhiyeti altı bölümde incelemektedir:

1. Hakikî Basit

2. Hakikî Mürekkep

3. İtibarî Vücûdî Basit

4. İtibarî Ademî Basit

5. İtibarî Vücûdî Mürekkep

6. İtibarî Ademî Mürekkep ${ }^{5}$

Hakikî mâhiyet, yalnızca vücûdî/varlıksal olabileceği için ademî/yokluksal hakikî mâhiyet söz konusu değildir. Fakat itibarî mâhiyet hakkında vücûdî gibi ademî kategori de mümkündür. Bu yüzden ister basit ister mürekkep olsun itibarî mâhiyet hakkında vücûdî ve ademî bölümleri söz konusu olduğu halde; hakikî mâhiyet hakkında yalnızca vücûdî bölüm söz konusu olmaktadır. Böylece mâhiyet altı bölümden oluşmaktadır. ${ }^{6}$

Basit, "muhtelif anlamlardan oluşmayan"; mürekkep, "muhtelif anlamlardan oluşan"; hakikî, "gerçek anlamda mevcûd olup hiçbir aklî varsayıma dayanmayan"; itibârî, "aklî varsayıma dayanan"; vücûdî,

Toshihiko Izutsu, İslamda Varlk Düşüncesi, çev. İbrahim Kalın (İstanbul: İnsan Yayınları, 1995), 112.

Şemseddin es-Semerkandî, Muhammed b. Eşref, es-Sahâifül'-îlâhiyye, thk. Ahmed Abdurrahman eş-Şerif, (Riyad: 1990), 99; el-Meâriff fi şerhi's-Sahâif, thk. Nazîr Muhammed Nazîr İyâd, Abdullah Muhammed Abdullah İsmail (Kahire: el-Mektebetü'l-Ezheriyye li't-Türâs, 2017-2018), 1/490; el-Mu'tekadât (İstanbul: Atıf Efendi Yazma Eser Kütüphanesi, 1369), 50b-51a; Behiştî, Ahmed el-i̇sferâinî, Eltâfü'l-letâif min halli’s-Sahâif (İstanbul: Süleymaniye Kütüphanesi, Cârullah Efendi,1212), 12a.

6 Semerkandî, el-Meârif, 1/490. 
"mefhumunda veya hakikatinde hiçbir olumsuzluk bulunmayan"; ademî ise "mefhumunda veya hakikatinde herhangi bir olumsuzluk bulunan" şeklinde tanımlanmaktadır.

Hakikî basit mâhiyet için "vâcip" ve "nokta" kavramları örnek verilmektedir. İtibârî basit mâhiyet için verilen örnek ise "varlığın varlığı"dır. Her şeyin bir varlığı olduğuna göre varlığın da varlığı akla gelmektedir. Fakat derin düşünüldüğünde varlığın varlığının varlığın kendisi olduğu anlaşılmaktadır. Zira mâhiyetin tahakkuku olarak tanımlanan varlık, tahakkuk etmek için başka bir şeye ihtiyaç duymaz. Aksi takdirde her tahakkuk için başka bir tahakkuk gerekir ve teselsül meydana gelir. Bu kural, tamladığ şeye özdeş olan her niteliğe teşmil edilebilir. Dolayısıyla husûlün husûlü, lüzûmun lüzûmu, birliğin birliği, kıdemin kıdemi gibi tamlamalar, yeni bir olguyu değil, tamlayan kavramların bizâtihî kendilerini ifade etmektedir. Hakikî mürekkep mâhiyet için "çeşitli organizmalardan oluşan beden" örnek verilmektedir. İtibârî mürekkep mâhiyet için verilen örnek ise "cins ve faslın terkibi"dir. Nitekim bu kavramlar, tümel olmaları hasebiyle dış dünyada değil, zihinde gerçekleşmektedir. Ayrıca "ç̧atı ve duvardan oluşan ev" hariçte terekküp ettiği için çatı veya duvar kavramlarından her birini eve hamlederek "Ev çatıdır." veya "Ev duvardır." yargısında bulunamayız. Fakat "hayvan ve nâtıktan oluşan insan" zihinde terekküp ettiği için canlı veya nâtık kavramlarından her birini insana hamlederek "Insan canlıdır." veya "İnsan nâtıktır." yargısında bulunabiliz. Semerkandî, hakikî mürekkep mâhiyet ile itibârî mürekkep mâhiyet arasındaki farkı bu şekilde ortaya koymaktadır. Semerkandî, "beyaz hayvan" gibi sıfat ve mevsufundan oluşan terkip ile "Mustafa ve Gevher" gibi farklı zâtlardan oluşan terkibi de itibarî mürekkep mâhiyet kapsamında değerlendirmektedir. ${ }^{8}$ Zira bu terkipler, her ne kadar dış dünyada tahakkuk eden bireylerden meydana gelse de iki zâtın "beraberliği" veya sıfatların zâtı "nitelemesi” dış dünyada gerçekleşmeyen aklî varsayımlardır.

Semerkandî, bu taksimat ve örneklem sonucunda bir mâhiyetin, hem hakikî hem de itibârî özellik sergileyebileceği kanaatine ulaşmaktadır. Söz gelimi "bir" kavramı, "vâcip" ve "nokta" örneklerinde hakikî anlam, "Türk Ordusu" gibi kolektif örneklerde ise itibârî anlam ihtiva etmektedir. Zira ordu, her ne kadar bir olsa da birçok askeri deruhte etmektedir. Yine "varlı" kavramı, eşyanın dış dünyada tahakkuku manasında hakikî anlam; "varlı̆̆ın varlığı" tamlamasında ise itibarî anlam ifade etmektedir. ' Zira mâhiyetin tahakkuku olarak tanımlanan varlık, tahakkuk etmek için başka bir şeye ihtiyaç duymaz. Aksi takdirde her tahakkuk için başka bir tahakkuk gerekir ve teselsül meydana gelir.

Şeylerin özünü teşkil eden mâhiyetler, varlık türlerinin belirlenmesinde önemli bir fonksiyona sahiptir. Nitekim hakikî mâhiyetler, hâricî mevcûdları; itibârî mâhiyetler ise zihnî mevcûdları oluşturmaktadır. ${ }^{10}$ Ayrıca mâhiyetlerin; basit ve bileşik kısımlarına ayrılması, Tanrı ile evren

Semerkandî, es-Sahâifü'l-ilâhiyye, 99; el-Meârif, 1/ 490-491; Behiştî, Eltâfü'l-letâif min halli's-Sahâif (Cârullah Efendi,1212), 12a.

8 Şemseddin es-Semerkandî, Muhammed b. Eşref, Kıstâsu'l-efkâr, çev. Necmettin Pehlivan (ìstanbul: Türkiye Yazma Eserler Kurumu Başkanlığı, 2014), 110; es-Sahâifü'l-ilâhiyye, 99-100; el-Meârif, 1/491-492.

9 Semerkandî, es-Sahâifül'-ilâhiyye, 100; el-Meârif, 1/493-495: el-Mu'tekadât (Atıf Efendi Yazma Eser Kütüphanesi, 1369), 50b-51a,

10 Semerkandî, filozofların paralelinde bilgi egemen bir varlık taksimi yaparak mevcûdu, zihnî mevcûd ve hâricî mevcûd olmak üzere ikiye ayırmaktadır. $O$, dış dünya gerçekliğindeki mevcûdu haricî mevcûd, zihinsel oluşuma sahip mevcûdu ise zihnî mevcûd olarak adlandırmaktadır. Semerkandî, zihnî varlığı kabul etmeyen kelamcıların 
arasındaki ontolojik farkı da belirginleştirmektedir. Çokluktan münezzeh olması ve zâtı gereği yalnızca zihinlerde değil, dış dünyada da mevcûd olması bakımından Tanrı, hakikî basit mâhiyet olarak değerlendirilmektedir. ${ }^{11}$ Semerkandî, mâhiyet içeriklerini ve bunların gerek kendi aralarındaki gerekse de mâhiyetle olan kavramsal ve yargısal ilişkilerini serimleyerek onto-teoloji ile mantık bilimleri arasında organik bir bağ kurmaktadır.

\section{Ontolojik Nüanslar}

Semerkandî, mevcûd ve vücûdî ile ma'dûm ve ademî kavramları arasındaki ince ayrıma dikkat çekmektedir. Semerkandî, bu kavramların bilinçsizce kullanımı sonucunda kimi zaman mevcûd ve vücûdî kavramlarıyla ma'dûm ve ademî kavramları özdeşleştirilirken; kimi zaman da vücûdî ve hakikî kavramlarıyla ademî ve itibârî kavramları arasında hiçbir fark gözetilmediğini beyan etmektedir. $^{12}$

Semerkandî, varlığı "oluş", yokluğu ise "oluşun bulunmaması" ile tanımlamaktadır. Dolayısıyla mevcûd, "bir oluşa sahip olan"; ma dûm ise "bir oluşa sahip olmayan" anlamlarına gelir. Semerkandî, vücûdî ile ademî kavramlarının tanımlanması konusunda birçok düşünürün hayret ve şaşkınlığa düştüğünü ifade etmektedir. $\mathrm{O}$, vücûdî kavramını, "öz anlamında ve hakikatinde herhangi bir olumsuzluk bulunmayan" olarak tanımlamaktadır. Dolayısıyla ademî kavramı da "öz anlamında ve hakikatinde herhangi bir olumsuzluk bulunan" anlamına gelmektedir. Körlük ve karanlık, ademî kavramlara örnek verilmektedir. Ademî kavram için olumsuzluk edatına itibar edilmez. Nitekim "adem/yokluk" ve "nefiy/olumsuzluk" gibi kavramlar, olumsuzluk edatı içermedikleri halde ademî bir anlam ihtiva ettikleri halde; "yok olmamak/el-lâ adem" kavramı, olumsuzluk edatı içerdiği halde vücûdî bir anlam ifade etmektedir. ${ }^{13}$

Ademî kavramlar, salt olumsuz bir anlamdan oluşabileceği gibi vücûdî ve olumsuz anlamların terkibinden de oluşabilmektedir. Salt olumsuz anlamdan oluşan ademî kavram için "adem" örnek verilmektedir. Vücûdî ve olumsuz anlamların terkibinden oluşan ademî kavram içinse "körlük" örnek gösterilmektedir. Zira ademî bir kavram olarak körlük, görme yetisinin bulunmaması gibi olumsuz bir anlam ile görme engelli olmak durumu gibi vücûdî bir anlamın terkibinden

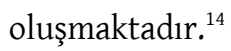

Semerkandî, ademî bir kavramın, vücûdî ve olumsuz anlamların terkibinden oluşabileceği ilkesine dayanarak iki mantıksal çıkarımda bulunmaktadır:

dayanağını anlamlandıramamaktadır. Zira bunların kabul etmedikleri şey, nesnelerin zihinde bizzât bulunması ise bunu hiç kimse kabul etmemektedir. Yok, eğer zihinde hiçbir şeyin bulunmadığını iddia ediyorlarsa bu da zorunlu bir bilginin inkârı anlamına gelmektedir. Dolayısıyla bunların zihnî varlığı kabul etmemelerinin tek nedeni, zihinde dış dünyaya mutabık bir misal oluştuğuna itiraz olabilir. Oysaki hiç kimse, düşündüğü sûret ya da mâhiyetin dış dünya gerçekliğine mutabık olduğunda şüphe duymamaktadır. Semerkandî, es-Sahâifü'l-ilâhiyye, 83; el-Meârif, I, 431434.

11 Semerkandî, bir nesnenin mâhiyetinin onun varlı̆̆ından başka bir şey olduğunu ve mantıksal olarak varlıktan önce geldiğini savunan kavramcı bir yaklaşımı benimsemektedir. Semerkandî, es-Sahâifü'l-ilâhiyye, 81-82; el-Meârif, I, 410411; Behiştî, Eltâfü'l-letâif min halli's-Sahâif (Cârullah Efendi, 1212), 7a.

12 Semerkandî, es-Sahâifü'l-ilâhiyye, 95-96; el-Meârif, 1/478-479.

13 Semerkandî, es-Sahâifü'l-ilâhiyye, 96; el-Meârif, 1/480; el-Mu'tekadât (Atıf Efendi Yazma Eser Kütüphanesi, 1369), 49b50a.

14 Semerkandî, es-Sahâifü'l-ilâhiyye, 96; el-Meârif, 1/480-481. 
Birinci çıkarım: Ademî olmak ma dûm hakkında doğru bir yargı ifade etmeyi gerektirmez. Zira söz konusu ademî kavrama içkin olan vücûdî bileşen, ma'dûm hakkında doğru bir yargı ifade etmez.

İkinci çıkarım: Ademî bir kavramın çelişiğinin vücûdî olması gerekmez. Zira söz konusu ademî kavramın çelişiği, ona içkin olan vücûdî bileşenin olumsuzlanması ile yapılırsa ademî bir kavramın çelişiği yine ademî bir kavram olabilir. ${ }^{15}$ Ademî bir kavramın çelişiğinin vücûdî olması gerekmediği halde vücûdî bir kavramın çelişiğinin ademî olması gerekmektedir. ${ }^{16}$ Zira vücûdî bir kavram için bir blok olarak olumlu olmak ve hiçbir olumsuzluğa karışmamak şart koşulduğu halde; ademî bir kavram için bir bileşeninin dahi olumsuz olması yeterli görülmüştür. Netice itibariyle blok olarak ya da bir bileşeni olumsuzluk içeren kavramlar ademî, bütün bileşenleri olumlu kavramlar ise vücûdî olarak değerlendirilmektedir. ${ }^{17}$

\section{Taayyün}

Mevcûdlar, aklî tahlil düzeyinde incelendiğinde varlık-mâhiyet gibi kurucu unsurların yanı sıra bu unsurlara ilişkin veya ekli sayılabilecek çeşitli nitelik ve durumlara da sahip olduğu gözlenmektedir. Mutlak varlık olan Tanrı'nın basit yapısı söz konusu olduğunda bu nitelik ve özelliklerin onun zâtında çokluk meydana getirebileceği şaibesi, çözümlenmesi gereken bir problem olarak ortaya çıkar. Mevcûdların kurucu unsurları olarak kabul edilen varlık ve mâhiyet dışında taayyün adını verdiğimiz varlığa ilişkin bir olgu daha saptanmaktadır. Dolayısıyla taayyün de varlığa ilişkin bir kavram olması bakımından onto-teolojik açıdan incelenmesi gereken bir kavramdır. Taayyünün varlık ve mâhiyetten başka bir şey olduğu açıktır. Zira mâhiyetin teşahhus etmesi anlamına gelen taayyün, hem mâhiyet hem de varlıktan bağımsız tasavvur edilmektedir. Şöyle ki; ortaklık ihtiva eden mâhiyetle özdeșleștirilemeyen taayyün, var olduktan sonra kazanılması nedeniyle de varlıktan farklı değerlendirilmektedir. Bir mevcûd olarak Tanrı'da da taayyün söz konusu olmaktadır. Tam da bu noktada taayyünün Tanrı'da çokluk meydana getirebileceği ve Tanrı'daki taayyünün başka bir illete ihtiyaç duyabileceği endişeleri gündeme gelmektedir. Taayyünün ademî olduğunu iddia eden kelâmcılar, tevhîd kaygısıyla dış dünyada mâhiyete ekli bir mevcûda karşı çıtıkları halde; taayyünün vücûdî olduğunu ileri süren İslâm filozofları ve muhakkik kelâmcılar ise dış dünyada mâhiyetle bir ve aynı olan taayyünün zihinsel ayrışmasına ve epistemolojik değerine vurgu yapmışlardır. Sonuçta her iki cenah da dış dünyada taayyünün mâhiyete özdeş olması yönünde hemfikir olsa da onto-epistemolojik düzlemde ihtilaf etmişlerdir. $^{18}$

Semerkandî’ye göre dış dünyada tahakkuk eden mâhiyet, kendine özgü birtakım anlamlar kazanır. Mâhiyete mahsus olan bu anlamlara taayyün veya teşahhus, bu anlam ve mâhiyetin birlikteliğine ise hüviyet adı verilir. Semerkandî taayyünü, "mevcûdu zihnî ve haricî varlıların tamamından

15 Semerkandî, es-Sahâifü'l-îlâhiyye, 96; el-Meârif, 1/481-482.

16 Semerkandî, es-Sahâifü'l-İlâhiyye, 96-97; el-Meârif, 1/ 482; Behiştî, Eltâfü'l-letâif min halli's-Sahâif (Cârullah Efendi, 1212), 11a-11b.

17 Semerkandî, mâhiyetlerin ontolojik durumu konusunda filozoflardan ayrışmaktadır. Zira o, filozofların zihin ve dış dünyadan soyutladıkları mutlak mâhiyeti dış dünyada mevcûd, zihinde mevcûd kabul ettikleri mücerred mâhiyeti de ma'dûm kabul etmektedir. Semerkandî, es-Sahâifü'l-îlâhiyye, 98; el-Meârif, I, 484-485.

18 Taayyün konusunda filozoflar ile kelâmcılar arasındaki ihtilaf için bkz. Cürcânî, Ali b. Muhammed es-Seyyid eş-Şerif, Şerhu'l-Mevākıffî ilmi'l-kelâm, çev. Ömer Türker (İstanbul: Türkiye Yazma Eserler Kurumu Başkanllğı, 2015), 1/650; Ahmet Arslan, Hâşiye ala’t-Tehâfüt Tahlili (İstanbul: Kültür ve Turizm Bakanlığı Yayınları, 1987) 255. 
ayrıştıran bir sıfat" olarak tanımlar. Taayyün, mâhiyete özdeş değildir. Zira taayyünün aksine mâhiyet için ortaklık söz konusudur. Ayrıca taayyün varlıkla da özdeşleştirilemez. Zira taayyün, varlıktan sonra kazanılan bir niteliktir. ${ }^{19}$

Semerkandî, taayyünün vücûdî bir mâhiyete sahip olduğunu iddia etmektedir. Zira hususiyet ifade eden taayyün, ademî olsaydı genellik ifade eden mutlaklık, tümellik, umumiyet ve benzeri özelliklerin yokluğu anlamına gelirdi. Bu durumda da taayyün, ya mutlaklığın yokluğu ya mutlaklığın yokluğundan ayrılmayan ya da mutlaklığın yokluğundan ayrılan bir şey olurdu. ìlk iki ihtimalde taayyün, mutlaklı̆̆ın yokluğu ve mutlaklığın yokluğundan ayrılmamak hususlarında tüm muayyen şeylere ortaktır. Ortaklık ise ayrışma vasfına sahip olan taayyün ile çelişir. Üçüncü ihtimalde ise muayyen olmayan bir mutlaklığın yokluğu ya da mutlaklığın yokluğu olmayan bir muayyen seçenekleri ortaya çıkar ki bunların her ikisi de imkânsızdır. Zira birinci durumda bir şeyin aynı anda ne mutlak ne de muayyen olması; ikinci durumda ise bir şeyin aynı anda hem mutlak hem de muayyen olmasi gerekir. ${ }^{20}$

Semerkandî, taayyünün vücûdî olduğunu iddia eden İslâm filozofları ve muhakkik kelâmcıların üç delilini analiz etmektedir:

Birinci delil: Râzîye göre taayyün, ademî olsaydı ya başka bir taayyünün yokluğu ya da taayyün olmamanın/el-lâ taayyün yokluğu olurdu. İki olumsuzdan bir olumlu meydana geldiği için ikinci ihtimalde taayyünün vücûdî olması gerekir. Birinci ihtimalde ise ikinci/başka taayyün ademî olursa ademî kabul ettiğimiz birinci taayyün, "Olumsuzun olumsuzu olumludur." kuralı gereğince vücûdî olur. İkinci taayyün vücûdî olursa onun benzeri olan birinci taayyünün de vücûdî olması gerekir. $^{21}$

Semerkandî, söz konusu delilde "el-lâ taayyün" ifadesi ile taayyünün yokluğu kastedilirse buradaki yokluğun, taayyün ve el-lâ taayyün ihtimalleri ile sınırlandırılamayacağını ifade etmektedir. Zira bu durumda siyah, beyaz, insan ve at gibi taayyün olmayan şeylerin yokluğu da üçüncü bir ihtimal olarak belirir. "el-Lâ taayyün" ifadesi ile taayyün olmayan her şey kastedilirse Razînin bu sınırlandırması kabul edilebilir. Fakat bu durumda da bir şeyin ademî olması lafzî olumsuzluk edatına bağlı olmadığı için "el-lâ taayyün" ifadesinin ademî olması gerekmez. Bu ifadenin ademî olduğu kabul edilse bile ademî bir şeyin çelişiğinin vücûdî olması gerekmez. Örneğin; "el-lâ amâ/görme engelli olmamak" ifadesi, olumsuzluk edatı içerdiği halde görme yetisine sahip olmak anlamında vücûdî bir anlam ihtiva etmektedir. ${ }^{22}$

İkinci delil: "Bu hayvan", bu hayvan olmak bakımından sâbittir. Sâbit olan bir şeyin parçası da sâbit olması gerektiğinden dolayı taayyün bildiren "bu" ifadesinin de sâbit olduğu ortaya çıar.

Semerkandî’ye göre bir şeyin sâbit olması onun sübûtî olmasını gerektirmez. Çünkü kimi ademî ifadeler sâbit oldukları halde onların vücûdî olduklarını iddia edemeyiz. Örneğin; görme engellilik, mâhiyeti bakımından sâbit olduğu halde bu kavram vücûdî değil, ademî kabul edilmektedir.

19 Semerkandî, es-Sahâifü'l-îlâhiyye, 108-109; el-Meârif, 1/524-526.

20 Semerkandî, es-Sahâifü'l-illâhiyye, 109; el-Meârif, 1/526-530.

21 Fahreddin er-Râzî, el-Metâlibü'l-âliyye fi'l-ilmi'l-îlâhî (Beyrut: Dâru'l-Kitâb el-Arabî, 1987), 1/305.

22 Semerkandî, es-Sahâifü'l-îlâhiyye, 110; el-Meârif, 1/531-532. 
Üçüncü delil: Taayyün, ademî olsaydı muayyen olamazdı ki bir başkasını tayin etsin.

Semerkandî’ye göre ise yokluklar, ayrışabilmeleri nedeniyle muayyen kabul edilmektedir. ${ }^{23}$

Semerkandî, taayyünün ademî olduğunu iddia eden kelâmcıların başlıca üç delilini analiz etmektedir:

Birinci delil: Taayyün, vücûdî olsaydı tümel bir mâhiyet kazanması nedeniyle başka taayyünlere ihtiyaç duyacağı için teselsül meydana gelirdi.

Semerkandî, taayyünlerin vücûdî olmaları halinde tümel bir mâhiyet kazanmasına itiraz etmektedir. Zira taayyünlerin, yalnızca lafzî iştirake sahip olarak farklı mâhiyetleri temsil etmeleri mümkündür. Bu durumdaki her mâhiyet aynı zamanda kendi taayyününü ifade eder.

İkinci delil: Taayyün, vücûdî olsaydı onun mâhiyete eklemi o mâhiyetin başka bir taayyün ile diğer mâhiyetlerden ayrışmasına bağlı olacağı için teselsül meydana gelirdi. Zira bir türe ait olan aynı mâhiyetlerin ayrışması bizâtihî değil, yalnızca bir ek/zait aracılığıyla gerçekleşir.

Semerkandî’ye göre bir türe ait olan aynı mâhiyetlerin ayrışması bir ekle değil, dış dünyaya ilişkin varoluşlarıyla (tahakkuk) gerçekleşmektedir.

Üçüncü delil: Türde ortakları olan şahıs, mâhiyet veya fâil ile taayyün ederse türlerin şahsa inhisarı gerekir. Söz konusu şahıs, maddesiyle taayyün ederse maddenin taayyünü de bașka bir maddeyle gerçekleşirse teselsül, maddenin kabul ettiği şahıs/taayyün ile gerçekleşirse de devir meydana gelir.

Semerkandî’ye göre türde ortakları olan şahsın "mâhiyet ve dışsal varlık" ya da "fâil" ile taayyün etmesi halinde türlerin şahsa inhisarı gerekmez. Fâil ile taayyün eden varlığın bir şahsa inhisar etmemesi bu iddiayı desteklemektedir. Ayrıca taayyünün, mâhiyet ile tahakkuk etmesi de mümkün olduğu için devir söz konusu değildir. Zira bir şeye tesir edebilmek, var olmaya bağlı olduğu için taayyünün henüz taayyün etmemiş mevcûd mâhiyet ile tahakkuk etmesinde hiçbir sakınca yoktur. $^{24}$

İslâm filozoflarının vâcip varlık hakkındaki kaygılarını yadsımayan Semerkandî’nin, taayyünü vücûdî olarak değerlendirmesi durumunda Tanrı hakkında çokluk ve nedenlilik şaibelerini nasıl ortadan kaldıracağına ilişkin bir sorun akla gelmektedir. Bu sorunu Semerkandînnin genel varlık felsefesi içerisinde cevaplandırmak mümkündür. Nitekim Semerkandî, varlı̆̆ı hakikî ve itibarî olmak üzere iki kısma ayırıp hakikî varlığı, "gerçek anlamda mevcûd olup hiçbir aklî varsayıma dayanmayan"; itibârî varlı̆̆ı ise "aklî varsayıma dayanan" şeklinde tanımlar. Dolayısıyla Semerkandî’nin, taayyün hakkında ifade ettiği vücûdî kavramını itibarî vücûdî mâhiyet kapsamında değerlendirmemiz durumunda Tanrı hakkında gerçek bir çokluk ya da nedenlilik ihtimalleri de söz konusu olmayacaktır.

23 Semerkandî, es-Sahâifü'l-ilâhiyye, 110; el-Meârif, 1/536-540.

24 Semerkandî, es-Sahâifü'l-îlâhiyye, 111; el-Meârif, 1/533-535. 


\section{Vücûb li-Zâtihî}

Vücûb kavramının mâhiyeti bakımından vücûdî mi, ademî mi olduğu konusu tartışmalıdır. Dışsal varoluş ile zâtı özdeşleştiren ontolojik bakış açısına sahip kelâmcılar, vücûb kavramını ademî kabul ederek vücûb sıfatına sahip, bir ve basit olan Tanrı'yı çokluktan tenzih etmek istemişlerdir. Semerkandı̂’nin de katıldığı muhakkik kelâmcılar ve İslam filozofları ise vücûb kavramına zihinsel bir mevcûdiyet yüklemenin Tanrı'da çokluk meydana getirebileceğini öngörmemişlerdir. Semerkandî, vücûb kavramını itibarî vücûdî mâhiyet kapsamında değerlendirmektedir. Zira vücûb, "zâtın zorunlu olarak varlığı gerektirmesi" anlamına gelmektedir. Varlığ1 gerektiren ya da varlığa vesile olan şeyin de varlığın hükmünü alması gerektiğinden dolayı vücûb, vücûdî mâhiyet kapsamında kabul edilmektedir. ${ }^{25}$ Ayrıca Semerkandî, vücûb kavramını dışsal varlıktan bağışık, zihinsel bir oluşum anlamında itibarî mâhiyet ile nitelendirerek Tanrı hakkında ortaya çıkabilecek olan çokluk şaibesinin de önüne geçmektedir.

Semerkandî, vücûbun vücûdî bir kavram olduğunu iddia edenlerin başlıca üç delilini analiz etmektedir:

Birinci delil: Vücûb, varlığın pekiştirilmiş halidir. Varlık, ademî bir şeyle pekiştirilemeyeceğine göre vücûb hükmünün de vücûdî olması gerekmektedir.

Semerkandî̀ye göre yokluk yeteneğinin olumsuzlanması da varlı̆̆ı pekiştirdiği halde olumsuzlama vücûdî değil, ademî bir kavramdır. Dolayısıyla varlığı pekiştiren şeylerin vücûdî olması gerekmemektedir.

İkinci delil: Varlığın devamlılığını ve kalıcılığını gerektiren vücûb kavramının da onun gibi vücûdî olarak değerlendirilmesi gerekmektedir.

Semerkandî’ye göre varlığın devamlılığını ve kalıcılığı gerektiren faktör vücûb sıfatı değil, zâtın kendisidir.

Üçüncü delil: Vücûb, ma'dûma yüklenen el-lâ vücûb/vâcip olmamak kavramının çelişiğidir. Ma'dûma yüklenen el-lâ vücûb kavramının onun gibi ademî olması gerektiğinden dolayı onun çelişiği olan vücûbun da vücûdî olduğu ortaya çıkar.

Semerkandî’ye göre ademî olanın çelişiği vücûdî olmak zorunda değildir. Ayrıca mantık ilmine göre mâ'dûl önerme, ${ }^{26}$ konunun vücûdî olmasını gerektirmektedir. Bu yüzden ma'dûm gibi ademî

25 Semerkandî, es-Sahâifüll-ïlâhiyye, 126; el-Meârif, 1/586.

26 Taraflarından birinde veya ikisinde olumsuzluk edatı bulunan yüklemli önermelere ma'dûl önerme denilmektedir. Olumsuzluk edatı konuda bulunursa ma'dûletü'l-mevzu olarak adlandırılır. “"اللا حى جماد" (canlı olmayan cemâddır) önermesi buna örnek verilebilir. Olumsuzluk edatı yüklemde bulunursa ma'dûletü'l-mahmûl olarak adlandırılır. "الحى لا جماد" (canlı olan cemâd olmayandır) önermesi buna örnek verilebilir. Hem konu hem de yüklem olumsuzluk edatı içerirse ma'dûletü’t-tarafeyn olarak adlandırılır. "اللا حى لا لا عالم" (canlı olmayan âlim olmayandır) önermesi buna örnek verilebilir. Bu önermelerdeki olumsuzluk edatları konu ile yüklem arasındaki nispeti/bağı değil, yalnızca birey olarak tarafları olumsuzlamaktadır. Bu yönüyle ma'dûl önermeler konu ile yüklem arasındaki nispeti olumsuzlayan selbî/olumsuz önermelerden ayrışmaktadır. Doğrusu ma'dûl önermeler, olumlu önermeler yanında olumsuz önermeler için de geçerlidir. “ليس كل لا حى جمادا" (her canlı olmayan cemâd değildir.) önermesi selbî ma'dûl önermeye örnek verilebilir. Kâtibî el-Kazvînî, Ebü’l-Hasen Necmüddîn Debîrân Ali b. Ömer b. Ali, eş-Şemsiyye filmantık, thk-çev-değ. Ferruh Özpilavcı (İstanbul: Litera Yayıncılık, 2017), 99-102. 
bir kavram ma'dûl önermenin konusu olamaz. Dolayısıyla ma'dûm hakkında mantıksal açıdan doğru bir yarg1, "Ma'dûm vücûb olmamaktır/el-lâ vücûb." şeklinde ma'dûl bir önermeyle değil, "Ma'dûm vücûb değildir." şeklinde selbî bir önermeyle mümkündür. Sonuç olarak delilde iddia edilen el-lâ vücûb kavramının ademî olması nedeniyle onun çelişiği olan vücûb kavramının vücûdî olması gibi bir durum da söz konusu olmaz. ${ }^{27}$

Semerkandî, vücûbun ademî bir kavram olduğunu iddia edenlerin başlıca üç delilini analiz etmektedir:

Birinci delil: Vücûb, vücûdî olsaydı ya zâtın kendisi ya parçası ya da zâtın dışında bir şey olurdu. Vücûb, nispet ifade ettiği için zâtın kendisi ya da bir parçası olamaz. Çünkü zât veya parça eşzamanlık, nispet ise sonralık ifade eder. Ayrıca bileşik yapıya neden olacağından dolayı vücûbu varlığa dâhil bir parça olarak değerlendirmek de doğru olmaz. Zira bileşik yapılar, birbirine ihtiyaç duymaları nedeniyle mümkün kategorisine girmektedir. Vâcibin aksine mümkün varlığın yok olması ise mümkündür. Zâtın dışında bir şey olması takdirinde ise vücûb, zâttan ayrık ve ona muhtaç olan mümkün bir varlığa evrilir. Dolayısıyla vücûbun ademî bir kavram olması gerekmektedir.

Semerkandî’ye göre mümkün varlıkları yokluğa mahkûm etmek yanlış bir genellemedir. Nitekim bi-zâtihî vâcip varlık gibi bi-gayrihî vâcip olan mümkün kökenli varlıklar da yok olamaz.

İkinci delil: Vücûb, vücûdî olsaydı diğer varlıklara ortak olduğu bir varlık yönü ile diğer varlıklardan ayrıldığı bir de hususi yönü olurdu. Ortaklık ve ayrılık başka şeyler olduğu için varlık ve mâhiyet birbirinden farklı değerlendirilirdi. Bu durumda onun mâhiyetinin varlıkla nitelenmesi vâcip olursa vücûbun vücûbu gibi bir teselsül, vâcip olmazsa da varlıktan ayrılması mümkün bir mâhiyete evrilmesi gerekir ki her iki ihtimal de geçersizdir.

Semerkandî̀ye göre delilde iddia edildiğinin aksine vücûbun vücûbu, vücûbun teselsülü değil, vücûbun bizzât kendisidir.

Üçüncü delil: Bu delil, Râzî tarafından ileri sürülmektedir. Ona göre vücûb, varlık ile hakikat arasında bir nispettir. Dolayısıyla vücûb, hakikatin dışında ve hakikat ile kâim mümkün bir varlıktır. Vâcip nedene dayanan her mümkün, vâcip varlı̆̆a evrilir. Vâcip zâta dayanması nedeniyle vücûdî kabul edilen vücûbun da henüz vâcip olmadan önce vâcip olması gerekir ki bu durum, imkânsızdır. ${ }^{28}$

Semerkandî’ye göre vâcibin vücûdu, onun zâtına ekli bir vücûd ile değil, vâcip zâtın gerektirdiği bir vücûd iledir. ${ }^{29}$

\section{6. İmkân}

İmkân kavramının mâhiyeti bakımından vücûdî mi, ademî mi olduğu konusu tartışmalıdır. İmkânın vücûdî olduğunu iddia eden İslâm filozofları, evrenin hiçliktense belirli bir şeyden yaratılmasını daha makul görmüşlerdir. Tanrı'yı ilk neden olarak konumlandıran İslâm

Semerkandî, es-Sahâifǜl-îlâhiyye, 126-127; el-Meârif, 1/586-588.

Fahreddin er-Râzî, Kitâbü'l-mülahhas fi'l-mantık ve'l-hikmet (Konya: Yusuf Ağa Yazma Eser Kütüphanesi, 9745), 160a.

Semerkandî, es-Sahâifü'l-îlâhiyye, 127-128; el-Meârif, 1/588-590. 
filozoflarına göre; evrenin kadîm olması Tanrı'nın birliğine aykırı değildir. Kıdem vasfını zamansal önceliğe tahsis etmeyen filozoflar, Tanrı ile evren arasında zâtî öncelik tasavvur etmişlerdir. Kıdem vasfını zamansal önceliğe indirgeyerek ulûhiyet ile kıdem niteliklerini adeta özdeşleştiren kelâmcılar ise Tanrı'nın ulûhiyetine zarar verebileceği endişesiyle evrenin kıdemini reddetmişlerdir. Kıdem kavramının yorumu ve bu kavrama yüklenen muhtelif anlamlar, İslâm filozoflarıyla kelâmcılar arasındaki ihtilafın en önemli nedenini oluşturur. İmkânın vücûdî bir mâhiyet olarak kabul edilmesi, Tanrı'nın mûcib bizzât, evrenin ise kadîm olmasını gerektirebileceği endişesiyle kelâmcılar, imkânı ademî bir mâhiyet olarak değerlendirmişlerdir. Semerkandî, imkânın mâhiyeti bakımından hakikî ademî ya da itibarî vücûdî bir mâhiyet olarak kabul edilmesi gerektiğini ifade etmektedir. ${ }^{30}$ Nitekim imkânın bu minvalde değerlendirilmesi Tanrı'nın mûcib bizzat, evrenin ise kadîm olması ihtimallerini de ortadan kaldırmaktadır.

Semerkandî, imkânın vücûdî olduğunu iddia eden filozofların başlıca üç delilini analiz etmektedir:

Birinci delil: İmkân, ademî olan imtinâ kavramının çelişiğidir. Ademî bir kavramın çelişiği vücûdî olmalıdır. Dolayısıyla imkân da vücûdî bir kavramdır.

Semerkandî̀ye göre imkân, imtinâ kavramının çelişiği değildir. Nitekim Râzî’ye göre de imkân, ademî olan imtinâ kavramının değil, vücûdî olan vücûb kavramının çelişiğidir. Ayrıca imkânın çelişiği imtinâ olsa bile ademî bir şeyin çelişiği vücûdî olmak zorunda değildir. ${ }^{31}$

İkinci delil: İ́n Sînâ’ya göre imkân, ademî olsaydı hiçbir şey özünde mümkün olmazdı. Zira “İmkânı yoktur." ile "Mümkün değildir." yargıları özdeștir. Dolayısıyla imkânı ademî kabul etmek imkânsız kabul etmekle eşdeğerdir. ${ }^{32}$

Semerkandî, söz konusu yargıların özdeşliğini kabul etmemektedir. Zira birinci yargı imkânın selbî bir sıfat olduğunu ifade ettiği halde; ikinci yargı imkânı külliyen reddetmektedir.

Üçüncü delil: İmkân, ma‘dûma yüklenen "el-lâ imkân/mümkün olmamak" kavramının çelişiğidir. Ma'dûma yüklenen şeyin ademî olması gerektiğine göre "el-lâ imkân" yükleminin ademî, onun çelişiği olan imkânın da vücûdî olması gerekmektedir.

Semerkandî’nin daha önce de açıkladığı üzere ademî bir kavramın çelişiği vücûdî olmak zorunda değildir. Ayrıca mantık ilmine göre mâ‘dul önerme, konunun vücûdî olmasını gerektirir. Bu nedenle ma'dûm gibi ademî bir kavram, ma'dûl önermenin konusu olamaz. Bu durumda doğru önerme, "Ma'dûm imkân olmamaktır/el-lâ imkân." şeklinde ma'dûl değil, "Ma'dûm imkân değildir." şeklinde selbî olarak kurulabilir. Dolayısıyla "el-lâ imkân" kavramının ademî, onun çelişiği olan imkân kavramının da vücûdî olması gibi bir durum da söz konusu olmaz. ${ }^{33}$

Semerkandî, imkânın ademî olduğuna ilişkin kelâmcıların ileri sürdüğü başlıca üç delili analiz etmektedir:

30 Semerkandî, es-Sahâifü'l-îlâhiyye, s. 131; el-Meârif, 1/598.

31 Fahreddin er-Râzî, Kitâbü'l-mülahhas fi'l-mantık ve'l-hikmet (Yusuf Ağa Yazma Eser Kütüphanesi, 9745), 162a.

32 Cürcânî, Şerhu'l-Mevâkıf, 1/676.

33 Semerkandî, es-Sahâifü'l-îlâhiyye, 128-129; el-Meârif, 1/591-594. 
Birinci delil: İmkân, vücûdî olsaydı mümkün, bilfiil varlıktan önce mevcûd olurdu. Bu durumda imkânın ya henüz mevcûd olmayan ma'dûm ile ya da başka bir zât ile kaim olması gerekirdi ki her iki ihtimal de geçersizdir.

İkinci delil: Varlık ile hakikat arasındaki nispeti ifade eden imkân, vücûdî olsaydı varlıktan sonra meydana gelirdi. Bu durumda da henüz imkân vasfiyla nitelenmeyen mümkün varlığın ya vâcip ya da mümteni' olması gerekirdi ki bu, imkânsızdır.

Semerkandî̀ye göre kelâmcıların ileri sürdüğü ilk iki delil, imkânın hakikî vücûdî mâhiyet olmadığını kanıtlasa bile onun itibarî vücûdî mâhiyet olmadığını kanıtlayamamaktadır. Zira Semerkandî, gerçek bir varlık olmaması hasebiyle itibarî varlığın, ma'dûm ile kaim olmasını da mümkün varlıktan önce var olmasını da mümkün görmektedir. Semerkandî, imkânın ademî olduğuna ilişkin kelâmcıların ileri sürdüğü ilk iki delili onun da karşı çıktığı imkânın hakikî vücûdî mâhiyet olma ihtimalini çürütebilmesi bakımından "hak burhan" olarak değerlendirmekte ve takdir etmektedir. Nitekim Semerkandî, kelâmcılar gibi imkânın hakikî ademî mâhiyet olmasının yanı sıra itibarî vücûdî mâhiyet olmasını da mümkün görmektedir.

Üçüncü delil: Râzi'ye göre imkân, vücûdî olsaydı diğer varlıklara ortak olduğu bir varlık yönü ile diğer varlıklardan ayrıldığı bir de hususi yönü olurdu. Ortaklık ve ayrılık başka şeyler olduğu için varlık ve mâhiyet birbirinden farklı değerlendirilirdi. Bu durumda onun mâhiyetinin varlıkla nitelenmesi mümkün olursa imkânın imkânı gibi bir teselsül, vâcip olursa da mümkün varlığın bizzât vâcip varlığa evrilmesi gerekir ki her iki ihtimal de geçersizdir.

Semerkandî’ye göre ise imkânın imkânı teselsül değil imkânın bizzât kendisidir. ${ }^{34}$

Semerkandî, ayrıca imkânı zamansal açıdan ikiye ayırmaktadır:

Birincisi, aslî imkândır. Bu kısım, zâtın varlık ya da yokluk taraflarından birini gerektirmediği zatî imkândır. Aslî imkân, zamansal açıdan eşyanın hudûsünden önce gelmektedir. Zira eşya, ancak varlık potansiyeline ve yeteneğine sahip olduktan sonra bilfiil mevcûd olur.

İkincisi, vukûî veya diğer adıyla isti'dâdî imkândır. Bu imkân türü, gerekli şartlar oluşup engelleyici nedenler ortadan kalktıktan sonra bilfiil varlığa hazır olmak anlamına gelmektedir. Filozoflara göre bu imkân türü, zamansal bakımdan eşyanın hudûsünden öncedir. Bu durumda nedensellik ilkesi gereği her hâdis, illet konumunda olan başka bir hâdisten sonra meydana gelir. Sonsuza kadar geri gidişi önlemek için söz konusu hâdisleri belirli bir zâta ve belirli bir vakte tayin edecek bir konuya ihtiyaç vardır ki bu, ezelî maddedir. Bu görüş, evrenin kadîm, Tanrı'nın ise mûcib bizzât olmasına sebebiyet verebileceği gerekçesiyle Semerkandî tarafından reddedilmiştir. Nitekim Semerkandî’ye göre vukûû imkânın, eşyanın hudûsünden önce değil de onunla eş zamanlı kabul edilmesi takdirinde filozofların ileri sürdüğü senaryo söz konusu olmayacaktır. ${ }^{35}$

Semerkandî, hakikî ademî mâhiyet ya da itibarî vücûdî mâhiyet olarak kabul ettiği aslî imkânın, eşyanın hudûsünden önce olmasını evrenin hudûsü ve Tanrı'nın iradesine aykırı bir durum olarak değerlendirmemiştir. Fakat o, hakikî vücûdî mâhiyet kapsamında değerlendirdiği vukûî imkânın, eşyanın hudûsünden önce olmasını evrenin hudûsü ve Tanrı'nın iradesiyle bağdaştırmayarak

34 Semerkandî, es-Sahâifü'l-ilâhiyye, 129-130; el-Meârif, 1/594-597.

35 Semerkandî, es-Sahâifü'l-îlâhiyye, 131; el-Meârif, 1/599-601. 
bunu eşyanın hudûsü ile eşzamanlı kabul etmiştir. Epistemolojik değere sahip "yokluk" ve "imkân" gibi kavramların hakikî vücûdî mâhiyet olarak değerlendirilmesi ontolojik manada kadîm varlıkların çokluğuna neden olabileceği endişesiyle Semerkandî tarafından itibarî vücûdî mâhiyet kavramı önerilmiştir. Böylece bu kavramlara gerçek bir varlık yükleme nedeniyle kadîm varlıkların çokluğu ihtimali ortadan kalkacağı gibi zihinde bir karşılığı olan ve başka şeylerden ayrışan bu kavramların epistemolojik değerleri de teslim edilmiştir.

\section{Sonuç}

Semerkandî, vücûdî ve ademî kavramlarının tanımlarına ve bunların arasındaki nüansa dikkat çekmektedir. O, vücûdî bir kavram için bir blok olarak olumlu olmayı ve hiçbir olumsuzluğa karışmamayı şart koştuğu halde ademî bir kavram için bir bileşeninin dahi olumsuz olmasını yeterli görmektedir.

İslam filozoflarının vâcip varlık hakkındaki kaygılarını eleştirmeyen Semerkandînnin, taayyün kavramını vücûdî olarak değerlendirmesi sonucunda Tanrı hakkında çokluk ve nedenlilik şaibelerini nasıl ortadan kaldıracağına ilişkin bir sorun akla gelmektedir. Semerkandî, varlı̆̆ı hakikî ve itibarî olmak üzere iki kısma ayırıp hakikî varlığı, "gerçek anlamda mevcûd olup hiçbir aklî varsayıma dayanmayan"; itibarî varlığı ise "aklî varsayıma dayanan" şeklinde tanımlamaktadır. Dolayısıyla Semerkandînin, taayyün hakkında ifade ettiği vücûdî kavramını itibarî vücûdî mâhiyet kapsamında değerlendirmemiz durumunda Tanrı hakkında gerçek bir çokluk ya da nedenlilik ihtimalleri de söz konusu olmamaktadır.

Semerkandî, vücûb kavramının itibarî vücûdî mâhiyete sahip olduğunu iddia etmektedir. Zira vücûb, zâtın zorunlu olarak varlı̆̆ gerektirmesi anlamına gelmektedir. Varlığı gerektiren şeyin de varlığın hükmünü alması gerektiğinden dolayı vücûb kavramının vücûdî olması gerekli görülmektedir. Ayrıca Semerkandî, vücûb kavramını dışsal varlıktan bağışık, bilişsel bir oluşum anlamında itibarî mâhiyet ile nitelendirerek Tanrı hakkında ortaya çıkabilecek bir çokluk ihtimalinin de önüne geçmektedir.

Semerkandî, imkânın mâhiyeti bakımından hakikî ademî ya da itibarî vücûdî bir mâhiyet olarak kabul edilmesi gerektiğini ifade etmektedir. Nitekim imkânın bu şekilde değerlendirilmesi Tanrı'nın mûcib bizzat, evrenin ise kadîm olması ihtimallerini de ortadan kaldırmaktadır.

Semerkandî ontolojisinde itibarî vücûdî mâhiyet kavramı kilit rol oynamaktadır. Zira Tanrı'ya isnat edilip de Tanrı'nın zâtında çokluk meydana getirebilecek ya da evrene isnat edilip de evrenin kadîm olmasını gerektirebilecek sıfatlar, itibarî vücûdî mâhiyet kapsamında değerlendirilerek söz konusu ihtimaller iptal edilmektedir. Böylece ontolojik risk oluşturan bu sıfatların zihinde bir karşıllı̆̆ olan ve başka şeylerden ayrışan epistemolojik değerleri de teslim edilmiştir. O, mâhiyet içeriklerini ve bunların gerek kendi aralarındaki gerekse de mâhiyetle olan kavramsal ve yargısal ilişkilerini serimleyerek onto-teoloji ile mantık bilimleri arasında organik bir bağ kurmaktadır. Semerkandî’nin varlık ve bilgi boyutlarını kapsayıcı nitelikte küllî bir perspektifle meseleleri tahlil ve sentezlemi, dil-düşünce-gerçeklik arasındaki ilişkinin daha sağlıklı bir şekilde tesis edilmesi adına bugün de işlevselliğini koruyan önemli bir yöntem olarak değerlendirilebilir. Onun bu konuda sergilediği eklektik yaklaşımı, varlık ve bilgi alanlarını müştereken ilgilendiren kavram ve problemlerin çözümlenmesinde rol model olabilir. 


\section{Çıkar Çatışması}

Makale yazarı Kader dergisi editör kurulunda görevlidir. Ancak yazarın makalesinin yayınlandığı bu sayıda editörlük görevi askıya alınmış ve editör yetkileri kaldırılmıştır. Bu bağlamda çift taraflı kör hakemlik ilkelerine uyulmuştur. 


\section{Kaynakça}

Arslan, Ahmet. Hâsşiye ala't-Tehâfüt Tahlili. İstanbul: Kültür ve Turizm Bakanlığı Yayınları, 1987.

Behiştî, Ahmed el-İsferâinî. Eltâfǘl-letâif min halli's-Sahâif. İstanbul: Süleymaniye Kütüphanesi, Cârullah Efendi,1212.

Cürcânî, Ali b. Muhammed es-Seyyid eş-Şerif. Şerhu'l-Mevākıf fî ilmi'l-kelâm. 1. Cilt. çev. Ömer Türker. İstanbul: Türkiye Yazma Eserler Kurumu Başkanlığı, 2015.

Fahreddin er-Râzî. el-Metâlibü'l-âliyye fi'l-ilmi'l-ilâhî. 1. Cilt. Beyrut: Dâru'l-Kitâb el-Arabî, 1987.

Fahreddin er-Râzî. Kitâbü'l-mülahhas fi'l-mantık ve'l-hikmet. Konya: Yusuf Ağa Yazma Eser Kütüphanesi, nr. 9745.

Kâdîzâde Rûmî. Şerhu Eşkâli't-te’sîs. İstanbul: Süleymaniye Kütüphanesi, Ayasofya, nr. 2712.

Kâtibî el-Kazvînî. Ebü'l-Hasen Necmüddîn Debîrân Ali b. Ömer b. Ali. eş-Şemsiyye fi'l-mantık. thkçev-değ. Ferruh Özpilavcı. İstanbul: Litera Yayıncılık, 2017.

Kâtip Çelebî. Süllemü'l-vusûl ilâ tabakāti'l-fuhûl. 3. Cilt. haz. Selahaddin Uygur. İstanbul: Merkezü'lEbhâs li't-Tarîh ve'l-Fünûn ve's-Sekāfe el-i̇slâmiyye, 2010.

Şemseddîn es-Semerkandî. Kelâm mecmuası. İstanbul: Süleymaniye Kütüphanesi, Laleli Koleksiyonu, nr. 2432.

Şemseddin es-Semerkandî, Muhammed b. Eşref. es-Sahâifü'l-ilâhiyye.thk. Ahmed Abdurrahman eşŞerif. Riyad: 1990.

Şemseddin es-Semerkandî. Kıstâsu'l-efkâr. çev. Necmettin Pehlivan. İstanbul: Türkiye Yazma Eserler Kurumu Başkanlığı, 2014.

Şemseddin es-Semerkandî. el-Meârif fi şerhi's-sahâif. 1. Cilt. thk. Nazîr Muhammed Nazîr İyâd, Abdullah Muhammed Abdullah İsmail. Kahire: el-Mektebetü'l-Ezheriyye li't-Türâs, 2017-2018.

Şemseddin es-Semerkandî. el-Mu'tekadât. İstanbul: Atıf Efendi Yazma Eser Kütüphanesi, 1369.

Toshihiko Izutsu. İslamda Varlık Düşüncesi. çev. İbrahim Kalın. İstanbul: İnsan Yayınları, 1995. 